\title{
Yerba Mate Consumption Effect on the Total Concentration of Creatine Phosphokinase in Healthy Volunteers from the Age of 50
}

\author{
Liza Ghassan Riachi, Paulo Sérgio Marcellini, Carlos Alberto Bastos de Maria, Geraldo Ceni Coelho
}

\begin{abstract}
This preliminary study investigated for the first time the effect of roasted yerba mate (Ilex paraguariensis A. St. Hil.) tea on total creatine phosphokinase (CPK) in volunteers from the age of 50 years. Volunteers were randomly assigned to intervention $(n=3)$ and control $(n=3)$ groups. Treated subjects consumed mate tea for 28 days $(500 \mathrm{~mL} /$ daily) and were submitted to five blood collection taken at intervals of seven days. It was observed a poor correlation between CPK level and yerba mate consumption. Results were also analyzed through cluster and principal component analyses. Treated and not treated subjects were not grouped into independent clusters which agreed with correlation analysis. Principal component analysis conferred partial discriminatory information about non-treated and treated groups. This study did not identify any influence of yerba mate consumption on total CPK concentration in physiological conditions. Larger sample studies should be addressed to detect significant small physiological variations in CPK values.
\end{abstract}

Index Terms- Roasted yerba mate; Serum creatine phosphokinase; Muscle physiology; Aging process.

\section{INTRODUCTION}

The consumption of yerba mate (Ilex paraguariensis A. St. -Hil.) was associated with several beneficial effects to human health $[1,2,3]$. A recent study [4] demonstrated that for 14 days, yerba mate tea consumption decreased CPK serum concentrations in institutionalized patients $(\mathrm{n}=4)$ with traumatic brain injury (TBI) when compared to control $(\mathrm{n}=$ 4). The CPK participates in the reversible phosphorylation reaction of creatine and seeks to maintain constant levels of ATP in cells that require high energy demand, such as muscle cells. The higher level of serum CPK is a trauma biomarker early after injury since the enzyme cannot cross the sarcoplasmic membrane barrier [5]. In patients with TBI, the values of CPK and other biochemical markers are monitored continuously in order to evaluate posttrauma events [4]. Despite the small sample in the study of Ribeiro et al. [4], the conjunction of principal component analysis with Person's correlation suggested, for the first time, positive correlation between yerba mate tea consumption and lower CPK levels in TBI patients.

Continuing the study of the effect of yerba mate

Published on 20 August, 2019.

L. G. R. Author is with Nursing and Biosciences Postgraduate Program, Nursing School (PPGENFBIO), Federal University of Rio de Janeiro State (UNIRIO), Brazil. (e-mail: lizagr00@gmail.com).

P. S. M. Author is with Biochemistry Department, Biomedical Institute UNIRIO, Rio de Janeiro, RJ, Brazil. (e-mail: marcellinips@yahoo.com).

C. A. B. M. Author is with the Collective Health Department, Biomedical Institute - UNIRIO, Rio de Janeiro, RJ, Brazil (e-mail: carreb@uol.com.br). consumption on CPK levels, our interest was to investigate, for the first time, this effect in non-institutionalized volunteers from the age of 50 years. At that age, people already show a progressive and physiological decrease of the skeletal muscle mass, originating from the aging process. Aging is a gradual and multifactorial process that is related to the progressive loss of organic functions and adaptive responses [6]. One of the effects of aging is the physiological loss of muscle mass. Between 20 and 80 years, human beings are expected to lose 20 to $30 \%$ of their skeletal muscle mass [7]. From the age of 50 years, there is a progressive decrease in muscle mass at the rate of 1 to $2 \%$ per year [8]. Given the Yerba mate's therapeutic potential in patients with TBI, our group aimed to investigate whether the consumption of mate tea can modulate serum concentrations of CPK under physiological conditions.

\section{Materials AND MethodS}

\section{A. Materials and yerba mate tea preparation}

Yerba mate leaves of I. paraguariensis A. St. Hil were harvested by the producers Claudio Kovaleski and Sílvio Kovalesky from "Ervateira Chiru” located to Chapecó, Santa Catarina State, Southern Brazil ( $27^{\circ} 09^{\prime} 05^{\prime \prime}$ S, $52^{\circ} 38^{\prime} 14^{\prime \prime}$ W), in November and December of 2014. Vouchers were examined by XXX to verify the identity of dried plants. A voucher specimen was deposited by the authors in the Herbarium Professor Jorge Pedro Pereira Carauta (Botanical Department, UNIRIO, Rio de Janeiro, Brazil) under the number HUNI 2344.

Yerba mate leaves were roasted at $200^{\circ} \mathrm{C}$ for $20 \mathrm{~min}$ in oven. To obtain infusions, boiling distilled water $(250 \mathrm{~mL})$ was poured over the plant material $(7.0 \mathrm{~g})$, mixed, capped and filtered under gravity after $15 \mathrm{~min}$.

\section{B. Participants and design study}

The study consisted of a randomized clinical trial. The volunteers were randomly assigned to two groups of equal numbers: control group (non-treated subjects, $n=3$ ) and intervention group (treated subjects, $\mathrm{n}=3$ ). Volunteers interested in the study completed a questionnaire containing personal information and data for assessing health conditions and life habits. The inclusion criteria were as follow: if

G. C. C. Author is with the Fronteira Sul Federal University, Rodovia SC 484 - Km 02, Fronteira Sul, CEP 89815-899, Chapecó, SC, Brazil. Environmental Science and Technology Postgraduate Program (PPGCTA), Federal University of Fronteira Sul (UFFS), Chapecó, Santa Catarina, Brazil (e-mail: cenicoelho@gmail.com, correspondence author).

Financial support: CAPES and CNPq. 
hypolipidemic medicament was used, the volunteer should have reached the minimum time of 3 months of treatment; the diabetic volunteer should have their blood glucose controlled. The exclusion criteria were as follow: renal failure; muscle or articulation disease; any uncontrolled illness; use of new drug therapy during the study; if volunteer stop taking yerba mate tea more than once or for more than two consecutive days.

The volunteers consumed yerba mate tea infusion twice a day ( $7 \mathrm{~g} 250 \mathrm{~mL}^{-1}$ each; a total of $500 \mathrm{~mL} /$ daily) for 28 days.

Before starting to consume yerba mate tea, the volunteers were submitted to the first blood collection. Soon after, the volunteers consumed the yerba mate tea, uninterruptedly. Five blood samples were taken at intervals of seven days between each collection, being a collection done before tea consumption and four collections during the 28 days of consumption. Throughout the study, volunteers were instructed to avoid drinking alcoholic beverages, teas, chocolate, and caffeinated beverages such as guarana, cola, and coffee. In addition, participants were instructed not to initiate any physical activity other than the usual routine. The non-treated volunteers followed a similar protocol of the treated ones, except for the consumption of mate. The staff of the clinical laboratory did the blood collection. The study was approved by the Official Ethics Committee of Human Research under the number CAAE: 44604215.0.0000.5285.

\section{Statistical}

Pearson's correlation was performed to verify the association between yerba mate tea consumption over the days with CPK serum concentration. Multivariate analysis was performed through Principal Component Analysis to observe the correlation between CPK variables and mate tea consumption and the Hierarchical Group Analysis (cluster analysis) to observe the grouping of analyzed data. For all inferences, $P<0.05$ was considered statistically significant.

\section{RESULTS}

The CPK concentrations of the treated and non-treated groups were compared after 28 days of study as illustrated in Figures 1, 2 and 3. In general, there was a poor Pearson's correlation between CPK level and mate tea consumption (Fig. 1).

The results for total CPK were further analyzed by means principal component and cluster analyses to observe the correlation via multivariate analysis. The dendrogram showed in Fig. 2 exhibited a similar tendency to Pearson's correlations analysis (Fig. 1). It was not possible to group into independent clusters both treated and not treated subjects. Further, there was a dissimilarity between volunteers of the same group.

On the other hand, it was possible to identify a partial grouping by principal component analysis not only in nontreated subjects but also in treated subjects (Fig. 3).

The first two principal components (F1 and F2) accounted for $67.89 \%$ of the total data variance and conferred partial discriminatory information about non-treated and treated groups.
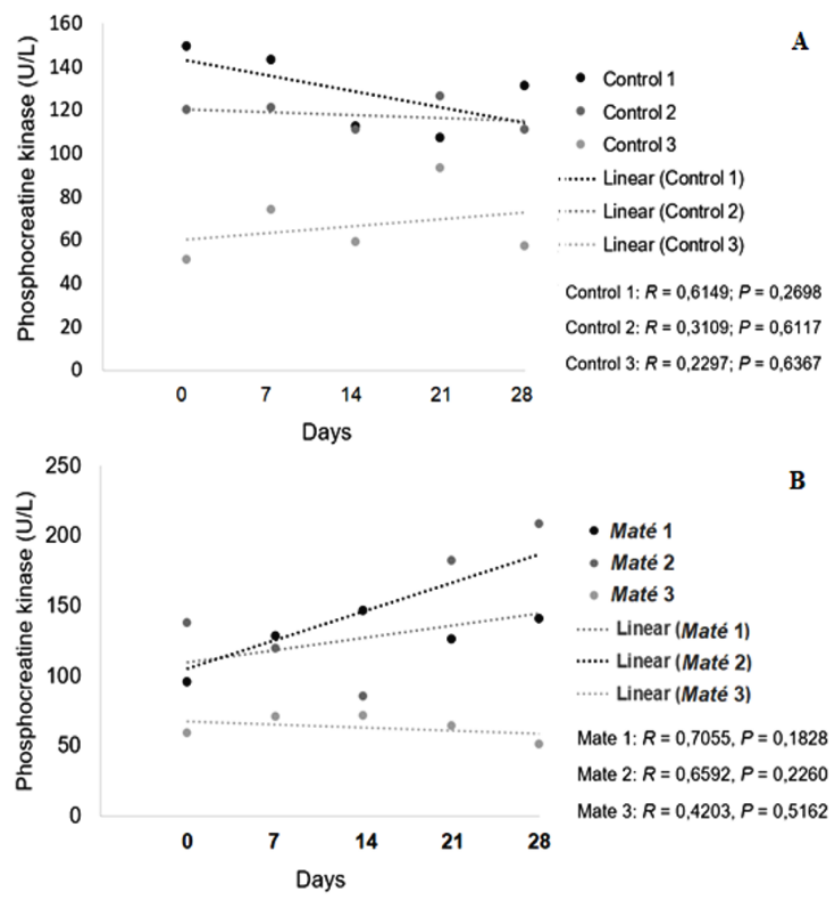

Fig. 1. Serum phosphocreatine kinase concentration of the non-treated (A) and treated (B) groups with yerba mate tea over 28 days of the study.

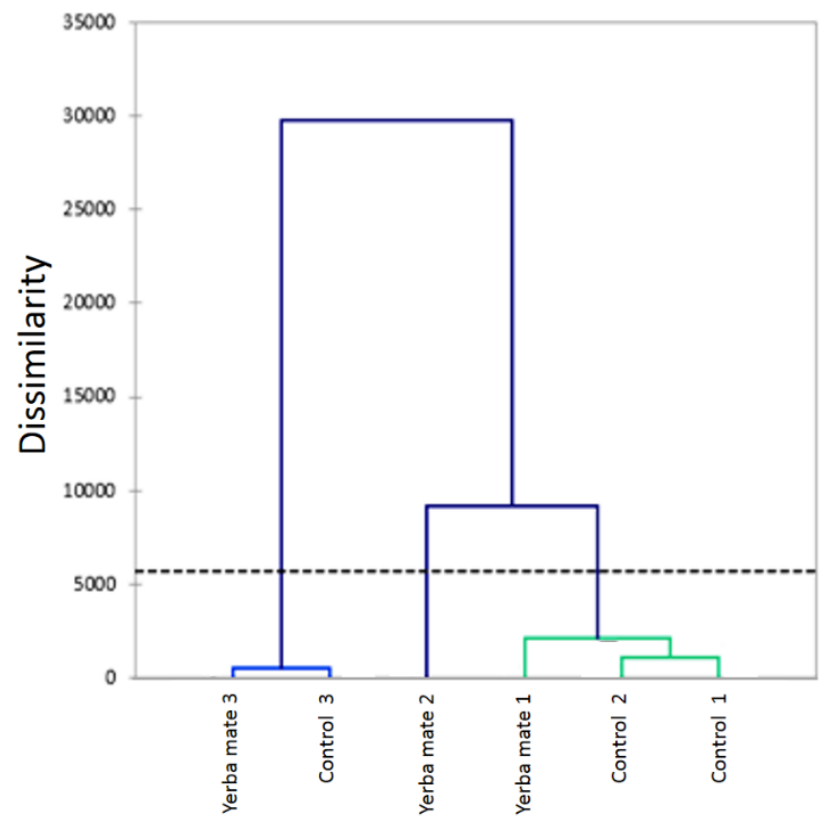

Fig. 2. Cluster analysis of the treated and non-treated groups with yerba mate tea, dashed line indicates sharp group partition.

\section{DISCUSSION}

This preliminary study was not closed to that from Ribeiro et al. [4], which identified a significant $(P<0.05)$ decrease of CPK concentration in yerba mate treated patients with TBI. Under the conditions used in the present study, it was not possible to identify any influence of yerba mate tea consumption on total CPK concentration. It could be hypothesized that the effects of yerba mate may be more evident in pathological conditions, where there are abnormal concentrations of total $\mathrm{CPK}$. In addition, it is possible that small physiological variations in CPK values, imperceptible 
when in a small sample, are identified in a larger sample study. More wide clinical studies are needed to confirm this hypothesis.

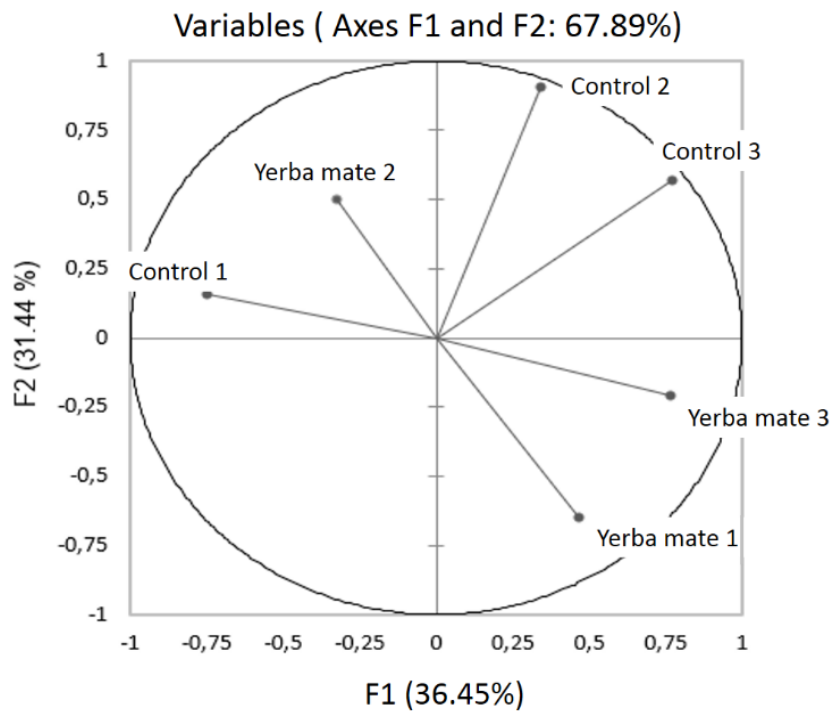

Fig. 3. Principal Component Analysis of total serum creatine phosphokinase in the treated and non-treated groups with yerba mate tea.

\section{ACKNOWLEDGMENT}

The authors thank the producers Claudio and Sílvio Kovalesky from the industry "Ervateira Chiru”, Chapecó, Santa Catarina State, Brazil.

\section{REFERENCES}

[1] N. Bracesco, A.G. Sanchez, V. Contreras, T. Menini, and A. Gugliucci, "Recent advances on Ilex paraguariensis research: Minireview", J. Ethnopharm., vol. 136, n. 3, pp. 378-384, 2011.

[2] C. I. Heck, and E. G. De Mejia, "Yerba Mate Tea (Ilex paraguariensis) a comprehensive review on chemistry, health implications, and technological considerations", J. Food Sci., vol. 72, n. 9, pp. 138-151, 2007.

[3] L. G. Riachi, and C. A. B. De Maria. "Yerba mate: An overview of physiological effects in humans", J. Funct. Foods; vol. 38, pp. 308320, 2017.

[4] M. C. Ribeiro, Â. Santos, L. G. Riachi, A. C. B. Rodrigues, G. C. Coelho, P. S. Marcellini, C. A. M. Bento, and C. A. B. De Maria, "The effects of roasted yerba mate (Ilex paraguariensis A. St. Hil.) consumption on glycemia and total serum creatine phosphokinase in patients with traumatic brain injury", J. Funct. Foods, vol. 28, p. 240 $245,2017$.

[5] G. Feier, S. S. Valvassori, G. T. Rezin, M. Búrigo, E. L. Streck, F. Kapczinski, and J. Quevedo, "Creatine kinase levels in patients with bipolar disorder: depressive, manic, and euthymic phases", Rev. Bras. Psiquiatr., vol. 33, n. 2, pp. 171-175, 2011.

[6] V. Lobo, A. Patil, A. Phatak, and N. Chandra, "Free radicals, antioxidants and functional foods: Impact on human health", Pharmacognosy Rev., vol. 4, n. 8, pp. 118-126, 2010.

[7] E. Carmeli, R. Coleman, and A. Z. Reznick, "The biochemistry of aging muscle", Exp. Geront., vol. 37, n. 4, pp. 477-489, 2002.

[8] E. Doria, D. Buonocore, A. Focarelli, and F. Marzatico. Relationship between human aging muscle and oxidative system pathway. Oxid. Med. Cel. Longev., vol. 2012, ID830257, pp. 1-13, 2012.

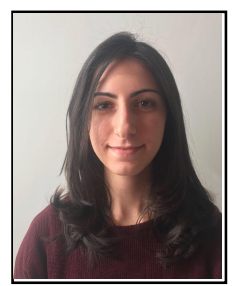

\section{Liza Ghassan Riachi}

Rio de Janeiro, Brazil, January 1990.

Master in Food and Nutrition, Federal University of Rio de Janeiro State, Rio de Janeiro, Brazil (2014). Doctor in Bioscience, Federal University of Rio de Janeiro State, Rio de Janeiro, Brazil (2018).

Her area of expertise is in food science and health. Some of her published articles includes:

1) L. G. Riachi, D. L. R. Simas, G. C. Coelho, P. S. Marcellini, A. J. Ribeiro da Silva, and C. A. Bastos De Maria. Effect of light intensity and processing conditions on bioactive compounds in maté extracted from yerba mate (Ilex paraguariensis A. St.-Hil.). Food Chem., vol. 266, pp. 317-322, 2018.

2) L. G. Riachi, and C. A. Bastos. Yerba mate: an overview of physiological effects in humans. J. Funct. Foods, vol. 38, pp. 308-320, 2017.

3) L. G. Riachi, and C. A. Bastos. Peppermint antioxidants revisited. Food Chem., v. 176, pp. 72-81, 2015.

\section{Paulo Sérgio Marcellini}

Bachelor's degree in Biochemical Pharmacy from São Paulo's State University Júlio de Mesquita Filho (UNESP, 1997), a Master's degree in Food and Nutrition (UNESP, 2000) and a PhD in Food and Nutrition from the State University of Campinas (UNICAMP, 2005). He is currently Associate Professor III of the State of Rio de Janeiro Federal University (UNIRIO), Biochemistry Department of the Biomedical Institute. He is a permanent member of the Programs: PhD in Nursing and Biosciences of the Federal University of the State of Rio de Janeiro, Professional Master's Degree in HIV/AIDS and Viral Hepatitis (PPGHIV/HV) in UNIRIO, and in the Program on Health and Technology in Hospital Space - Professional Master's Program (PPGSTEH) - UNIRIO.

\section{Carlos Alberto Bastos de Maria}

Graduation in Nutrition, Rio de Janeiro State Federal University, Brazil (UNIRIO, 1987), master in Biochemistry (UNIRIO, 1991) and doctorate in Biochemistry (UNIRIO, 1995). He is currently titular professor at UNIRIO, with experience in Food Science and Technology, focusing on Chemistry, Physics, Chemical-physics, Biochemistry of Food and Alimentary Raw materials.

\section{Geraldo Ceni Coelho}

Biologist, Master in Botany (UFRGS - Rio Grande do Sul Federal University, Porto Alegre, Brazil, 1996), Doctor in Pharmaceutical Sciences (UFRGS, 2002), He works on chemical ecology, ecophysiology and forest ecology. Member of the Post-Graduation in Environmental Science and Technology, Fronteira Sul Federal University, UFFS, Brazil. 